\begin{tabular}{ll}
\hline \hline MINING AND METALLURGY INSTITUTE BOR & ISSN: 2334-8836 \\
& UDK: 622 \\
\hline \hline
\end{tabular}

UDK: $622.83: 550.8 .013(045)=111$

DOI:10.5937/MMEB1403041L

\author{
Suzana Lutovac ${ }^{*}$, Zoran Gligoric ${ }^{*}$ Čedomir Beljić, ${ }^{*}$ Marina Ravilic ${ }^{*}$
}

\title{
DERIVATION THE SOIL OSCILLATION LAW AND DETERMINATION OF ITS PARAMETERS ${ }^{* *}$
}

\begin{abstract}
This paper gives an analysis the method for determining the parameters of soil oscillation law, suggested by Professor M. A. Sadovski as well as the level of its applicability for blasting with commercial explosives for the needs of mining and other economic activities. The applicability of this law was analyzed on examples of mass blasting at the Open Pit "Drenovac" that are carried out for deposit mining.

As the relation between the soil oscillation velocity and basic parameters affecting its magnitude, are the following: the amount of explosive, distance from the blasting site, characteristics of the rock material and type of blasting, the equation of $M$. A. Sadovski, where the oscillation velocity $v$ is given in the form of of the function, is most frequently used:

$$
v=K \cdot R^{-n}
$$

where $R$ is reduced distance, and $K$ and $n$ parameters conditioned by soil characteristics and blasting conditions, thereby $v$ is decreasing and convex function of variable $R$.

To determine parameters in the equation of Sadovsi, in addition to the common method of least squares, another model was applied. There by, it has been stated that both models can be used to calculate the oscillation velocity of the rock mass.
\end{abstract}

Keywords: working environment, blasting, rock destruction, seismic effect, oscillation velocity, soil oscillation law

\section{INTRODUCTION}

For evaluation and control the seismic effect of blasting, as well as to plan it, the determination of soil oscillation law is required, with the strike: blasting field - facilities to be protected [12]. One of the most commonly used equations is that of M.A. Sadovski defining the law of alteration in oscillation velocity of soil depending on distance, explosive amount and conditions of blasting and geological characteristics of the soil, being determined on the basis of test blasting for the specific work environment.
By application the law of rock mass oscillation in blasting, determination of soil oscillation velocity is enabled for each blast operation in advance, thus blasting is, as regards seismic effect, under control, which gives an opportunity to plan the magnitude of shock waves for each future blast operation [2]. In this way, the adverse blasting effects are reduced. Adverse effects of blasting imply, in addition to the seismic ones, those of air blast waves, fly rock mass, etc. [14]. Thus the production efficiency is in

\footnotetext{
* University of Belgrade, Faculty of Mining and Geology, Djušina 7, 11000 Belgrade, Serbia, e-mail:suzana.lutovac@rgf.bg.ac.rs,zoran.gligoric@rgf.bg.ac.rs; cedomir.beljic@rgf.bg.ac.rs;

** This paper has resulted from the Project No. 33025 and 33029, funded by the Ministry of Education of the Republic of Serbia, realized by the Faculty of Mining and Geology in Belgrade
} 
creased and, at the same time, construction and mining facilities, as well as the environment in the vicinity of the blast site, are protected.

\section{SOIL OSCILLATION LAW}

To establish the correlation between the oscillation velocity and three basic parameters affecting its size: the explosive quantity, properties of rock material and distance, several mathematical models are developed in the world. One of most frequently used models, i.e. equations, is the equation of Sadovski defining the law on velocity alteration of soil oscillation depending on distance, explosive amount and blasting method [9]. The law, defined in this way, offers the possibility to determine the seismic effect of blasting towards a structure or settlement, whereby the connection, between the velocity of soil oscillation and consequences that can affect facilities, is used. The equation of M.A Sadovski is given in the form:

$$
v=K \cdot\left(\frac{r}{\sqrt[3]{Q}}\right)^{-n}
$$

where there are:

$\mathrm{V}$ - velocity of soil oscillation $[\mathrm{cm} / \mathrm{s}]$

$\mathrm{K}$ - coefficient conditioned by soil characteristics and blasting conditions, determined by terrain surveying,

$\mathrm{n}$ - exponent conditioned by characteristics of soil and blasting conditions, determined by field measurements,

$\mathrm{r}$ - distance from the blasting site to the monitoring point $[\mathrm{m}]$,

Q - amount of explosive [kg].

\subsection{Derivation the equation of rock mass oscillation law}

\subsubsection{Derivation the equation of rock mass oscillation - the I way}

The equation of Sadovski was derived from the condition: if the radius of charge and distance from the blasting site to the monitoring point increase in the same or approximately the same ratio, the soil oscillation velocity remains the same [1 pp. 42 and 43], that is :

$$
v=K_{v} \cdot\left(\frac{r_{o}}{r}\right)^{n},
$$

where there is

$\mathrm{r}_{\mathrm{o}}$-radius of explosive charge [m],

$\mathrm{r}$ - distance from the blasting site to the monitoring point [m].

Radius of explosive charge $\left(\mathrm{r}_{0}\right)$ and amount of explosive (Q) are related by equation:

$$
Q=\frac{4}{3} \cdot \pi \cdot r_{o}^{3},
$$

from where there is:

$$
r_{o}=\sqrt[3]{\frac{3 \cdot Q}{4 \cdot \pi}} .
$$

By replacing the value $\left(\mathrm{r}_{\mathrm{o}}\right)$ from equation (4), in $t$ equation, the following is obtained (2):

$$
\begin{aligned}
& v=K_{v} \cdot\left(\frac{\sqrt[3]{\frac{3 \cdot Q}{4 \cdot \pi}}}{r}\right)^{n}=K_{v} \cdot\left(\sqrt[3]{\frac{3}{4 \cdot \pi}}\right)^{n} \cdot\left(\frac{\sqrt[3]{Q}}{r}\right)^{n}= \\
& =K_{v} \cdot K_{1} \cdot\left(\frac{r}{\sqrt[3]{Q}}\right)^{-n}=K \cdot\left(\frac{r}{\sqrt[3]{Q}}\right)^{-n}=K \cdot R^{-n}
\end{aligned}
$$

where :

$$
\begin{aligned}
& \left(\sqrt[3]{\frac{3}{4 \cdot \pi}}\right)^{n}=K_{1} ; \\
& K_{v} \cdot K_{1}=K ; \\
& \frac{r}{\sqrt[3]{Q}}=R .
\end{aligned}
$$

$\mathrm{R}$ - reduced distance or derived distance is the one from the blasting site to the monitoring point reduced to the amount of explosive, being given in the form $R=\frac{r}{r_{0}}$. 
Thus, the oscillation law of rock mass is obtained, i.e. the Sadovski equation in the form :

$$
v=K \cdot R^{-n}
$$

\subsubsection{Derivation the equation of rock mass oscillation - the II way}

If, in blasting in the specific environment, the relative increase in oscillation velocity of the rock mass and relative increase of reduced distance are monitored, then it can be seen that their relations at various levels have approximately the same value [8(A)] which will be marked (-n), meaning that:

$$
\frac{\frac{\Delta v}{v}}{\frac{\Delta R}{R}} \approx-n
$$

Thereby, it can be considered that:

$$
\lim _{\Delta R \rightarrow 0} \frac{\frac{\Delta v}{v}}{\frac{\Delta R}{R}}=-n,
$$

which means that is :

$$
\frac{\frac{d v}{v}}{\frac{d R}{R}}=-n .
$$
form:

Equation (7) can be written in the

$$
\frac{d v}{v}=-n \cdot \frac{d R}{R},
$$

where by integration, it is obtained:

$$
\int \frac{d v}{v}=-n \cdot \int \frac{d R}{R},
$$

namely:

$$
\log v=\log R^{-n}+\log K
$$

where:

$\mathrm{K}$ - constant of integration.

Equation (8) can be written in the form:

$$
\log v=\log k \cdot R^{-n},
$$

from where, it is obtained:

$$
v=K \cdot R^{-n},
$$

being the equation of rock mass oscillation of M. A. Sadovski.

The equation of Sadovski is commonly shown in the form:

$$
v=K \cdot Q_{r e d}^{n}
$$

where:

$\mathrm{Q}_{\text {red }}$ - reduced amount of explosive

$$
Q_{\text {red }}=\frac{\sqrt[3]{Q}}{r}
$$

where:

$\mathrm{R}$ - distance from the blasting site to the monitoring point $[\mathrm{m}]$,

$\mathrm{Q}$ - overall amount of explosive in a mine series [kg].

\subsection{Models of determination the soil oscillation law parameters}

There are two parameters $\mathrm{K}$ and $\mathrm{n}$ in equation (5) which should be determined for the specific work environment and IN particular blasting conditions. Regarding to the characteristics of the rock mass oscillation law, it is possible to determine the parameters $K$ and $n$ in a number of ways, i.e. models, thereby using the values obtained by experimental measurements.

\subsubsection{Determination of parameters by model 1}

The smallest square method is mainly used to obtain the parameters $(\mathrm{K})$ and $(\mathrm{n})$, which represent the common model [3]. Equation (5) uses logarithms and thus is reduced to the following form:

$$
\log v=\log K-n \log R
$$

By introduction the replacement: $\mathrm{v}=\mathrm{y} ; \mathrm{K}=\mathrm{a} ; \mathrm{R}=\mathrm{x} ; \mathrm{n}=\mathrm{b}$; the equation gets the following form:

$$
\log a-b \log x=\log y
$$


Normal equation system for finding parameters (a) and (b) in this case is:

$$
\begin{aligned}
& N \log a-b \sum_{i=1}^{N} \log x_{i}=\sum_{i=1}^{N} \log y_{i} \\
& (\log a) \sum_{i=1}^{N} \log x_{i}-b \sum_{i=1}^{N}\left(\log x_{i}\right)^{2}=\sum_{i=1}^{N} \log x_{i} \cdot \log y_{i}
\end{aligned}
$$

where:

$\mathrm{N}$ - is the number of carried out surveys

\subsubsection{Determination of parameters by model 2}

Starting from the rock mass oscillation law from the equation (5):

$$
v=K \cdot R^{-n},
$$

which is derived by different way (Chapter 2.1.2), whereby the parameter $\mathrm{K}$, occurring as constant of integration [8(B)], can be determined from conditions (initial condition) that for $\mathrm{R}=\mathrm{R}_{1}$ is $\mathrm{v}=\mathrm{v}_{1}$.

Parameters $\mathrm{K}$ and $\mathrm{n}$ will be determined using the experimental data of pairs $\left(\mathrm{R}_{\mathrm{i}}, \mathrm{V}_{\mathrm{i}}\right), \mathrm{i}$ $=1,2, \ldots, \mathrm{N}$, provided that the curve of oscillation velocity of rock mass passes through the point $\mathrm{M}_{1}\left(\mathrm{R}_{1}, \mathrm{v}_{1}\right)$. In that case, out of (5) for $R=R_{1}$ and $v=v_{1}$, the following is obtained:

$$
v_{1}=K \cdot R_{1}^{-n},
$$

where:

$$
K=v_{1} \cdot R_{1}^{n} .
$$

By replacement thevalues for $\mathrm{K}$ from (14) in equation (5), the equation is obtained:

$$
v=v_{1} \cdot\left(\frac{R_{1}}{R}\right)^{n} .
$$

From equation (15), for $\mathrm{R}=\mathrm{R}_{1}$ there is obtained $\mathrm{v}=\mathrm{v}_{1}$ for any $\mathrm{n}$, in the case $\mathrm{n}>0$. For $\mathrm{R}=\mathrm{R}_{\mathrm{i}}, \mathrm{i}=2,3, \ldots, \mathrm{N}$, from the equation (15), it can be taken that:

$$
v_{i}=v_{1} \cdot\left(\frac{R_{1}}{R_{i}}\right)^{n}, \mathrm{i}=2,3, \ldots, \mathrm{N},
$$

from where the relation is obtained:

$$
v_{1} \cdot v_{2} \cdot \ldots \cdot v_{N}=v_{1}^{N} \cdot\left(\frac{R_{1}^{N}}{R \cdot{ }_{1} R_{2} \cdot \ldots \cdot R_{N}}\right)^{n} .
$$

From relation (16), parameter $\mathrm{n}$ can be determined. By logarithm operation of relation (16), the following is obtained:

$$
n \log \left(\frac{R_{1}^{N}}{R_{1} \cdot R_{2} \cdot \ldots \cdot R_{N}}\right)=\log \left(\frac{v_{1} \cdot v_{2} \cdot \ldots \cdot v_{N}}{v_{1}^{N}}\right),
$$

where the following is found:

$$
n=\frac{\log \left(\frac{v_{1} \cdot v_{2} \cdot \ldots \cdot v_{N}}{v_{1}^{N}}\right)}{\log \left(\frac{R_{1}^{N}}{R_{1} \cdot R_{2} \cdot \ldots \cdot R_{N}}\right)} .
$$

By replacement the value for parameter $\mathrm{n}$ in equation (17), found in this way, the relation for oscillation velocity of rock mass in monitored environment is obtained:

$$
v=v_{1} \cdot\left(\frac{R_{1}}{R}\right)^{n} .
$$

Thus, to determine the parameter $\mathrm{n}$, all experimental data were taken into account.

\section{DEFINING THE STATISTICAL CRITERIA}

To evaluate the degree of correlation between recorded (measured) and calculated data in this work, the coefficient of linear correlation $r$ [5] between logarithm of reduced distance $\mathrm{R}$ and logarithm of the oscillation velocity $\mathrm{v}$ was used. Additionally, the curve line dependency index $\rho[6(\mathrm{~A})]$ between the reduced distance $\mathrm{R}$ and oscillation velocity $\mathrm{v}$ was also taken into account.

Evaluation the relationship degree of two variables [13] to values of the curve 
line dependency index $\rho$ is given in the follo-wing survey:

$0.0<\rho<0.2-$ none or highly poor correlation,

$0.2<\rho<0.4$ - poor correlation,

$0.4<\rho<0.7$ - significant correlation,

$0.7<\rho<1.0-$ strong or highly strong correlation.

The same is valid for absolute value of linear correlation coefficient $r$.

As a convenience measure of the obtained functional relationship for the given experimental data, the criterion , $3 \mathrm{~S}^{\text {“ }}$ was also used [6(B)]. This criterion uses squares of differences between the obtained experimenal data and the calculated ones for oscillation velocities of $\mathrm{v}$. If those differrences are one after another $\varepsilon_{1}, \varepsilon_{2} \ldots \varepsilon_{\mathrm{N}}$, then it is :

$$
S=\sqrt{\frac{\varepsilon_{1}^{2}+\varepsilon_{2}^{2}+\ldots+\varepsilon_{N}^{2}}{N}}
$$

According to this criterion, for evaluation the convenience of obtained functional correlation, the following relations are valid:

- If it is $\left|\varepsilon_{\max }\right|>3 \mathrm{~S}$, the obtained functional correlation is rejected as unfavorable,

- If it is $\left|\varepsilon_{\max }\right|<3 \mathrm{~S}$, the functional correlation is accepted as a good one.

\section{SURVEY OF MASS BLASTING AT THE OPEN PIT "DRENOVAC"}

\subsection{General characteristics of the open pit "Drenovac"}

This work includes research, carried out during mass blasting at the open pit "Drenovac" in Mionica [7(A)]. The open pit "Drenovac" is of elevated type and it is situated almost at the very top of the hill of the same name.

The limestone deposit covers the surface of 7.7 ha. The altitude difference of the deposit is about $70 \mathrm{~m}$ from the elevation 440-520. There is a diabase - chert formation in the floor of limestone, approximately at the elevation of $438 \mathrm{~m}$.

The limestone is of fissure porosity as stated by mapping of both the terrain and test bore holes. The length of cores is from 30 to $40 \mathrm{~cm}$. Cracks and fissures are mostly filled with calcite, and to a lesser extent they are filled with limonite debris, namely limonite dross. During drilling, circulation losswater was insignificant, which points to low effective porosity of limestone.

Limestone is a firm petrified environment. It is tectonically undamaged thus it represents a unique monolithic mass. The impact of present cracks and fissured is insignificant on physico-mechanical characteristics.

The following values were obtained by testing the physico-mechanical properties of the working environment:

$$
\begin{array}{ll}
\text { - volume mass } & 2.68\left[\mathrm{kN} / \mathrm{m}^{3}\right] \\
\text { - porosity } & 0.7-1.5[\%] \\
\text { - cohesion } & 0.25[\mathrm{MPa}] \\
\text { - uniaxial strength } & \\
\text { - in dry state } & 120-134[\mathrm{MPa}] \\
\text { - in water saturated state } & \multicolumn{2}{c}{83-129[\mathrm{MPa}]} \\
\multicolumn{3}{c}{\text { - angle of internal friction } 41\left[^{\circ}\right] .}
\end{array}
$$

\subsection{Blasting method}

Measurements of seismic shock waves at the open pit "Drenovac", carried out during blasting, were conducted in order to exploit the deposit [7(B)]. Eight blasting operations were carried out.

The amonex-1 28/200, amonex-1 60/1000, ANFO-J in bags of $25 \mathrm{~kg}$ and ANFEX-PP 70/1500 were used as explosives. The explosive was activated in boreholes by nonel detonators, marked $\mathrm{N}$ 25/500 and K-42 connectors. Basic data, related to the number of boreholes $\left(\mathrm{N}_{\mathrm{b}}\right)$, overall explosive amount $\left(\mathrm{Q}_{\text {total }}\right)$, maximum explosive amount by deceleration interval $\left(\mathrm{Q}_{\mathrm{i}}\right)$, overall borehole depth $\left(\mathrm{L}_{\text {total }}\right)$, and average stemming length $\left(\mathrm{L}_{\mathrm{sl}}\right)$, are present in Table 1. 
Table 1 Survey of blasting parameters

\begin{tabular}{|c|c|c|c|c|c||}
\hline \hline Blasting & $\mathbf{N}_{\mathbf{b}}$ & $\mathbf{Q}_{\text {total }}[\mathbf{k g}]$ & $\mathbf{Q}_{\mathbf{i}}[\mathbf{k g}]$ & $\mathbf{L}_{\text {total }}[\mathbf{m}]$ & $\mathbf{L}_{\mathbf{s l}}[\mathbf{m}]$ \\
\hline \hline I & 27 & 661.4 & 36.2 & 211.0 & $2.8-3.0$ \\
\hline II & 28 & $1,980.6$ & 71.2 & 488.0 & $2.8-3.0$ \\
\hline III & 15 & 915.3 & 66.2 & 213.0 & $2.8-3.0$ \\
\hline IV & 16 & 745.0 & 47.0 & 175.0 & $3.0-3.2$ \\
\hline V & 40 & $1,895.0$ & 60.5 & 453.0 & $3.0-3.2$ \\
VI & 22 & $1,774.4$ & 85.2 & 402.0 & $3.0-3.2$ \\
\hline VII & 43 & $1,988.6$ & 54.2 & 518.0 & $3.0-3.2$ \\
VIII & 20 & 600 & 32.0 & 273.0 & $3.0-3.0$ \\
\hline \hline
\end{tabular}

The record of soil oscillation velocity is shown in Figure 1. for blasting number 1 - measuring point 3

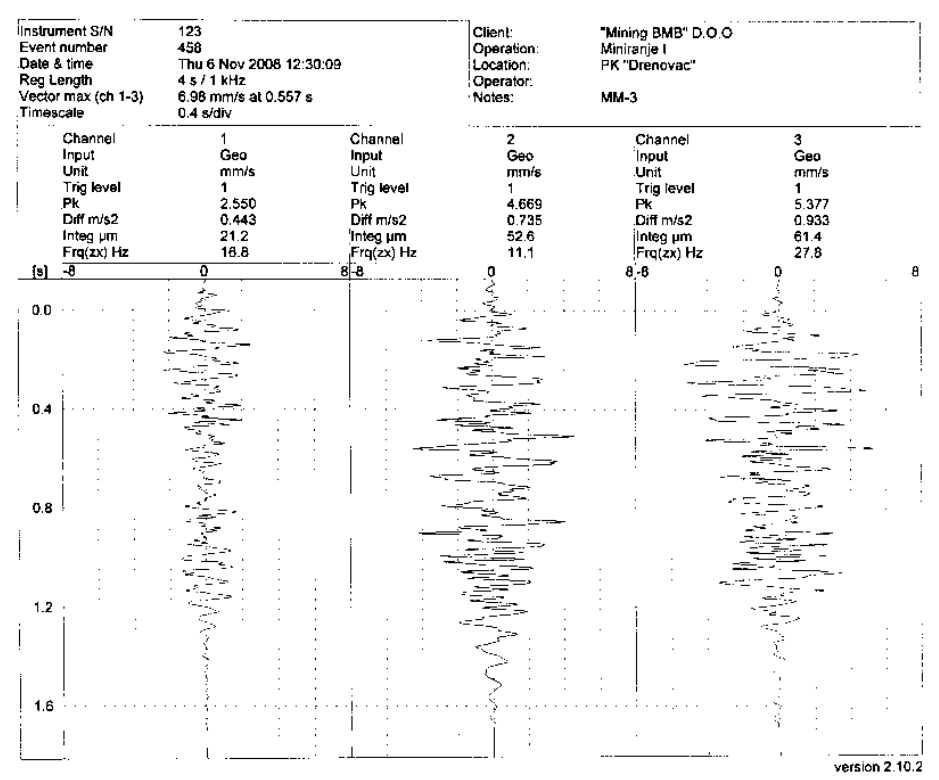

Figure 1 Image of soil oscillation velocity for blasting I-MM3

\subsection{Calculation the soil oscillation law parameters}

Table 2 gives the values of distances from blast sites to monitoring points $r$, the amount of explosive Q , calculated values of reduced distances $\mathrm{R}$, recorded values of soil oscillation velocities by components $\mathrm{v}_{\mathrm{t}}, \mathrm{v}_{\mathrm{v}}, \mathrm{v}_{\mathrm{l}}$ and resulting oscillation velocities $v_{\text {rez }}$ for blasting from I to VIII of totally seven measuring points MM. 
Table 2 Survey of blasting parameters and measurement results

\begin{tabular}{|c|c|c|c|c|c|c|c|c|c|}
\hline No. & $\begin{array}{c}\text { Blas- } \\
\text { ting }\end{array}$ & MM & $\mathbf{r}[\mathbf{m}]$ & $Q[\mathrm{~kg}]$ & $\mathbf{R}$ & $\begin{array}{c}\mathbf{v}_{\mathrm{t}} \\
{[\mathrm{cm} / \mathrm{s}]}\end{array}$ & $\begin{array}{c}\mathbf{v}_{\mathbf{v}} \\
{[\mathrm{cm} / \mathrm{s}]}\end{array}$ & $\begin{array}{c}v_{1} \\
{[\mathrm{~cm} / \mathrm{s}]}\end{array}$ & $\begin{array}{c}\mathbf{V}_{\mathrm{rez}} \\
{[\mathrm{cm} / \mathrm{s}]}\end{array}$ \\
\hline 1 & I & $\mathrm{MM}-2$ & 383.87 & 661.4 & 44.0585 & 0.070 & 0.100 & 0.110 & 0.1643 \\
\hline 2 & I & $\mathrm{MM}-3$ & 250.49 & 661.4 & 28.7499 & 0.255 & 0.466 & 0.537 & 0.7616 \\
\hline 3 & I & $\mathrm{MM}-5$ & 647.42 & 661.4 & 74.3073 & 0.080 & 0.090 & 0.080 & 0.1446 \\
\hline 4 & II & MM - 1 & 605.54 & 1980.6 & 48.2182 & 0.060 & 0.060 & 0.070 & 0.1100 \\
\hline 5 & II & $\mathrm{MM}-2$ & 334.15 & 1980.6 & 26.6078 & 0.080 & 0.120 & 0.150 & 0.2081 \\
\hline 6 & II & $\mathrm{MM}-3$ & 256.71 & 1980.6 & 28.4042 & 0.510 & 0.500 & 1.090 & 1.3031 \\
\hline 7 & II & $M M-6$ & 527.05 & 1980.6 & 41.9681 & 0.090 & 0.230 & 0.160 & 0.2943 \\
\hline 8 & IIII & $\bar{~} \mathrm{MM}-1$ & "616.35 & 9915.3 & 63.4804 & 0.091 & 0.083 & 0.082 & 0.1482 \\
\hline 9 & III & $M M-2$ & 250.14 & 915.3 & 25.7629 & 0.192 & 0.573 & 0.719 & 0.9392 \\
\hline 10 & III & $M M-3$ & 412.66 & 915.3 & 42.5015 & 0.380 & 0.605 & 0.412 & 0.8247 \\
\hline 11 & III & $M M-5$ & 714.10 & 915.3 & 73.5481 & 0.138 & 0.096 & 0.116 & 0.2045 \\
\hline 12 & III & $M M-6$ & 541.13 & 915.3 & 55.7332 & 0.170 & 0.241 & 0.177 & 0.3454 \\
\hline 13 & III & $\mathrm{MM}-7$ & 530.89 & 915.3 & 54.6785 & 0.133 & 0.236 & 0.193 & 0.3326 \\
\hline 14 & IV & MM - 1 & 723.77 & 745.0 & 79.8390 & 0.060 & 0.080 & 0.070 & 0.1221 \\
\hline 15 & IV & $M M-2$ & 410.33 & 745.0 & 45.2635 & 0.140 & 0.170 & 0.180 & 0.2844 \\
\hline 16 & IV & $M M-3$ & 223.89 & 745.0 & 24.6973 & 0.310 & 0.420 & 0.540 & 0.7511 \\
\hline 17 & IV & $M M-5$ & 644.64 & 745.0 & 71.1102 & 0.110 & 0.200 & 0.200 & 0.3035 \\
\hline 18 & IV & $\mathrm{MM}-7$ & 426.38 & 745.0 & 47.0339 & 0.200 & 0.230 & 0.210 & 0.3701 \\
\hline 19 & $\mathrm{~V}$ & MM - 1 & 737.38 & 1895.0 & 60.0667 & 0.050 & 0.070 & 0.040 & 0.0948 \\
\hline 20 & V & $\mathrm{MM}-3$ & 210.96 & 1895.0 & 17.1847 & 0.550 & 0.790 & 1.150 & 1.4996 \\
\hline 21 & $\mathrm{~V}$ & $\mathrm{MM}-7$ & 422.53 & 1895.0 & 34.4192 & 0.210 & 0.360 & 0.320 & 0.5254 \\
\hline 22 & VI & $\overline{~ M M-3}$ & 231.44 & 17774.4 & 19.1171 & 0.577 & $\begin{array}{l}1.160 \\
\end{array}$ & 0.709 & $\begin{array}{l}1.4768 \\
\end{array}$ \\
\hline 23 & VI & $M M-5$ & 650.53 & 1774.4 & 53.7341 & 0.055 & 0.071 & 0.077 & 0.1165 \\
\hline 24 & VI & $\mathrm{MM}-6$ & 640.06 & 1774.4 & 52.8693 & 0.081 & 0.150 & 0.168 & 0.2393 \\
\hline 25 & VI & $\mathrm{MM}-7$ & 425.36 & 1774.4 & 35.1350 & 0.340 & 0.465 & 0.259 & 0.6316 \\
\hline 26 & VII & $\overline{M M}-3$ & 333.13 & 1988.6 & 26.4910 & 0.534 & 0.460 & 0.602 & 0.9268 \\
\hline 27 & VII & $M M-6$ & 530.48 & 1988.6 & 42.1845 & 0.101 & 0.190 & 0.150 & 0.2623 \\
\hline 28 & VII & $\mathrm{MM}-7$ & 415.31 & 1988.6 & 33.0260 & 0.284 & 0.525 & 0.286 & 0.6618 \\
\hline 29 & VIII & $\mathrm{MM}-1$ & 609.20 & 600.0 & 72.2286 & 0.030 & 0.070 & 0.070 & 0.1034 \\
\hline 30 & VIII & $M M-3$ & 387.35 & 600.0 & 45.9254 & 0.339 & 0.527 & 0.629 & 0.8878 \\
\hline 31 & VIII & $M M-6$ & 532.35 & 600.0 & 63.1171 & 0.067 & 0.112 & 0.079 & 0.1607 \\
\hline 32 & VIII & $M M-7$ & 493.85 & 600.0 & 58.5524 & 0.072 & 0.157 & 0.156 & 0.2327 \\
\hline
\end{tabular}

Based on data, given in Table 2, the soil oscillation law is calculated by formula (5) by the models 1 and 2 . The calculation of curve was carried out for values of reduced distances from $\mathrm{R}=17.1847$ to $\mathrm{R}=$ 79.8390.Thus, the curve parameters were calculated enabling to determine the equation of soil oscillation in the form of:

\section{- Model 1}

$$
v_{1}=166.3916 \cdot R^{-1.6433}
$$

where by the linear dependence between $\log \mathrm{v}$ and $\log \mathrm{R}$ is obtained, expressed by equation (20), with the linear correlation coefficient (r) amounting:

$$
\mathrm{r}=-0.8
$$

Graphic survey of soil oscillation law is shown in Figure 2. 


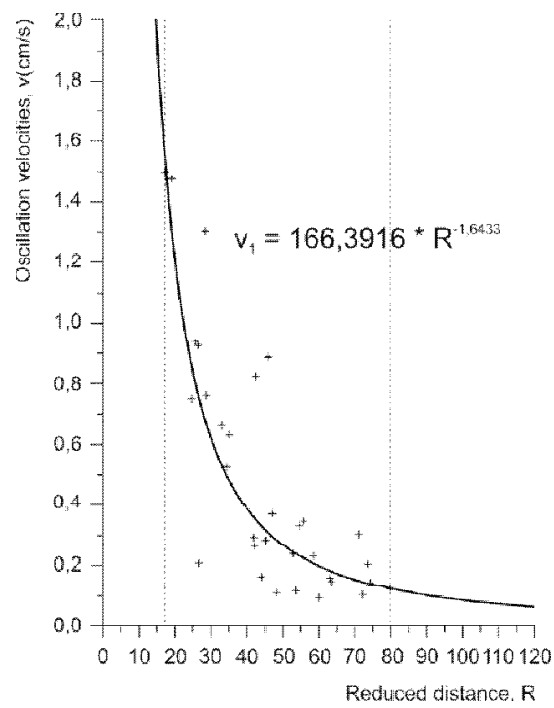

Figure 2 Graphic survey of soil oscillation law curve at the open pit Drenovac

\section{- Model 2}

$$
v_{2}=143.2699 \cdot R^{-1.6032}
$$

Based on the obtained equations of soil oscillation (20) and (21), it is possible to calculate values of soil oscillation velocities for corresponding reduced distances for models 1 and 2 .
Table 3 presents the survey of reduced distances $\mathrm{R}$, recorded oscillation velocities $\mathrm{V}_{\mathrm{r}}$, calculated oscillation velocities $\mathrm{V}_{\mathrm{i} 1}, \mathrm{v}_{\mathrm{i} 2}$ as well as the difference between recorded and calculated soil oscillation velocities for models 1 and 2.

Table 3 Survey of recorded and calculated soil oscillation velocities for models 1 and 2

\begin{tabular}{|c|c|c|c|c|c|c|}
\hline No. & $\mathbf{R}$ & $v_{\mathbf{r}}[\mathbf{c m} / \mathbf{s}]$ & $v_{i 1}[\mathrm{~cm} / \mathrm{s}]$ & $v_{\mathrm{i} 2}[\mathrm{~cm} / \mathrm{s}]$ & $\mathbf{v}_{\mathbf{r}}-\mathbf{v}_{\mathbf{i} 1}$ & $v_{r}-v_{i 2}$ \\
\hline 1 & 44.0585 & 0.1643 & 0.3307 & 1.4996 & -0.1664 & 0.0000 \\
\hline 2 & 28.7499 & 0.7616 & 0.6670 & 1.2641 & 0.0946 & 0.2127 \\
\hline 3 & 74.3073 & 0.1446 & 0.1401 & 0.8384 & 0.0045 & -0.0873 \\
\hline 4 & 48.2182 & 0.1100 & 0.2852 & 0.7835 & -0.1752 & 0.1557 \\
\hline 5 & 26.6078 & 0.2081 & 0.7576 & 0.7493 & -0.5495 & 0.1775 \\
\hline 6 & 28.4042 & 1.3031 & 0.6804 & 0.7440 & 0.6227 & -0.5359 \\
\hline 7 & 41.9681 & 0.2943 & 0.3583 & 0.6700 & -0.0640 & 0.6331 \\
\hline 8 & 63.4804 & 0.1482 & 0.1815 & 0.6572 & -0.0333 & "0.1044 \\
\hline 9 & 25.7629 & 0.9392 & 0.7988 & 0.5262 & 0.1404 & 0.1356 \\
\hline 10 & 42.5015 & 0.8247 & 0.3509 & 0.4924 & 0.4738 & 0.0330 \\
\hline 11 & 73.5481 & 0.2045 & 0.1425 & 0.4765 & 0.0620 & 0.1551 \\
\hline 12 & 55.7332 & 0.3454 & 0.2248 & 0.3583 & 0.1206 & -0.0640 \\
\hline 13 & 54.6785 & 0.3326 & 0.2319 & 0.3554 & 0.1007 & -0.0931 \\
\hline 14 & 79.8390 & 0.1221 & 0.1245 & 0.3512 & -0.0024 & 0.4735 \\
\hline 15 & 45.2635 & 0.2844 & 0.3164 & 0.3315 & -0.0320 & -0.1672 \\
\hline 16 & 24.6973 & 0.7511 & 0.8562 & 0.3174 & -0.1051 & -0.0330 \\
\hline 17 & 71.1102 & 0.3035 & 0.1506 & 0.3101 & 0.1529 & 0.5777 \\
\hline
\end{tabular}




\begin{tabular}{||c|c|c|c|c|c|c||}
\hline 18 & 47.0339 & 0.3701 & 0.2971 & 0.2985 & 0.0730 & 0.0716 \\
\hline \hline 19 & 60.0667 & 0.0948 & 0.1987 & 0.2868 & -0.1039 & -0.1768 \\
\hline 20 & 17.1847 & 1.4996 & 1.5539 & 0.2475 & -0.0543 & -0.0082 \\
\hline 21 & 34.4192 & 0.5254 & 0.4963 & 0.2411 & 0.0291 & -0.1246 \\
\hline \hline 22 & 19.1171 & 1.4768 & 1.3043 & 0.2345 & 0.1725 & 0.0981 \\
\hline 23 & 53.7341 & 0.1165 & 0.2387 & 0.2274 & -0.1222 & 0.1180 \\
\hline 24 & 52.8693 & 0.2393 & 0.2451 & 0.2101 & -0.0058 & 0.0226 \\
\hline 25 & 35.1350 & 0.6316 & 0.4798 & 0.2017 & 0.1518 & -0.1069 \\
\hline \hline 26 & 26.4910 & 0.9268 & 0.7631 & 0.1863 & 0.1637 & -0.0256 \\
\hline 27 & 42.1845 & 0.2623 & 0.3552 & 0.1846 & -0.0929 & -0.0364 \\
\hline 28 & 33.0260 & 0.6618 & 0.5311 & 0.1539 & 0.1307 & 0.1496 \\
\hline \hline 29 & 72.2286 & 0.1034 & 0.1468 & 0.1501 & -0.0434 & -0.0467 \\
\hline 30 & 45.9254 & 0.8878 & 0.3089 & 0.1458 & 0.5789 & 0.0587 \\
\hline 31 & 63.1171 & 0.1607 & 0.1832 & 0.1434 & -0.0225 & 0.0012 \\
\hline 32 & 58.5524 & 0.2327 & 0.2073 & 0.1278 & 0.0254 & -0.0057 \\
\hline 3
\end{tabular}

\section{CONCLUSION}

Based on the data in Table 3, a statistical analysis was carried out and the following values were obtained:

\section{for Model 1:}

The curve line dependency index $\rho_{l}$ between the reduced distance $\mathrm{R}$ and soil oscillation velocity is:

$$
\begin{aligned}
& \rho_{1}=0.8380 \text { (there is a strong correlation } \\
& \text { between } \mathrm{R} \text { an } \mathrm{v} \text {, given in } \\
& \text { formula }(20) \text { ). }
\end{aligned}
$$

Maximum difference between the recorded and calculated oscillation velocities of the $\operatorname{soil}\left(\varepsilon_{\max }\right)=\max \left|\varepsilon_{i}\right|$, amounts:

$$
\begin{aligned}
& \varepsilon_{\max 1}=0.6227, \mathrm{~S}_{1}=0.2200, \\
& 3 \mathrm{~S}_{1}=0.6600
\end{aligned}
$$

As there is $\varepsilon_{\max 1}<3 \mathrm{~S}_{1}$, the supposed functional relationship is accepted as a good one.

\section{for Model 2:}

$$
\begin{gathered}
\rho_{2}=0.8357 \text { (there is a strong correlation } \\
\text { between } \mathrm{R} \text { an } \mathrm{v} \text {, given in } \\
\text { formula }(21) \text { ). } \\
\varepsilon_{\max 2}=0.6331, \mathrm{~S}_{2}=0.2214, \\
3 \mathrm{~S}_{2}=0.6642 . \\
\varepsilon_{\max 2}<3 \mathrm{~S}_{2} \text { (supposed functional rela- } \\
\text { tionship is accepted as a } \\
\text { good one). }
\end{gathered}
$$

To establish the relationship between the oscillation velocity of the rock mass and basic parameters affecting its magnitude, the followings are: the amount of explosive, distance from the blasting site, characteristics of the rock mass and type of blasting, it is the equation of M. A. Sadovski that is used most commonly. It defines the law on alteration in the oscillation velocity of the rock mass and is given in the form of function:

$$
v=K \cdot R^{-n},
$$

where $\mathrm{R}$ is reduced, i.e. derived distance, and parameters $\mathrm{K}$ and $\mathrm{n}$ the coefficient and exponent conditioned by characteristics of the soil and conditions of blasting and can have only the positive values. Thereby, $\mathrm{v}$ is a decreasing and convex function.

In this work, the law of Sadovski is also derived in another way using the quotient of relationship between the relative increase in oscillation velocities of the rock mass and relative increase of reduced distances. Thereby, in a marginal case, a differential equation, whose general integral overlaps with the law of Sadovski, is obtained.

In this paper, the oscillation velocity is calculated, i.e. the parameters $\mathrm{K}$ and $\mathrm{n}$ are determined in two ways - models. Based on the analysis and data processing, it can be concluded: 
The parameters $\mathrm{n}$ and $\mathrm{K}$ in Sadovski law are determined in two ways - models in the specific work environment. Thereby, the obtained corresponding functions present the oscillation velocities of the rock mass depending on reduced distance. The calculated corresponding indexes of the curve line correlation point out that there is a highly strong curve line relationship between the reduced distance and oscillation velocity of the rock mass, expressed in the obtained functions.

Comparing the values of recorded oscillation velocities of the rock mass with the corresponding calculated ones, it can be seen that they are approximately the same. On the basis of obtained values of curve line dependency coefficients and the values of linear correlation coefficients between the reduced distance logarithm and oscillation velocity logarithm, it can be concluded that both models can be used for calculating the oscillation velocity of the rock mass.

\section{REFERENCES}

[1] Medvedev S. V. (1964): Seismika gornwh vzrwvov, Nedra, Moskva, pp. 42-43.

[2] Trajković S., Slimak Š., Lutovac S. (2005): Technique of Blasting and Eartquakes, Faculty of Mining and Geology, Belgrade, pp. 199 (in Serbian);

[3] Simeunović D. (1985): Mathematics, Faculty of Mining and Geology - Mining Department, Belgrade, pp. 102103 (in Serbian);

[4] Ivanović B. (1973): Theoretical Statistics, Naučna knjiga, Belgrade, pp. 90 (in Serbian);

[5] Simonović V. (1995): Introduction to the Theory of Probability and Mathematical Statistics, TEKON - Tehnokonsalting, Belgrade (in Serbian);

[6] Vukadinović S. (1970): Elements of Probability and Mathematical Statistics, Technique for Copying of the Bureau of Construction, Belgrade, pp. 329-331(A) (in Serbian);

[7] Trajković S., Lutovac S., Katona O. (2009): Study of Seismic and Air
Impacts on the Surrounding Building Structures as the Result of Blasting at the Open Pit "Drenovac" near Mionica, Faculty of Mining and Geology, Belgrade, pp. 3-4(A), pp. 15-51(B) (in Serbian);

[8] Lutovac S. (2010): Model for Determining the Parameters of the Law of Oscillation of the Rock Mass in Blasting, Ph.D. Thesis, Faculty of Mining and Geology, Belgrade, pp. 34-35(A), pp. 40-41(B) (in Serbian);

[9] Savić M. (2000): Blasting at the Open Pits, Monograph, RTB Bor, Copper Institute Bor, Indok Center, Bor pp. 317 (in Serbian);

[10] Fokin V. A., Tarasov G. E., Togunov M. B., Danilkin A. A., Šitov Y. A. (2008): Soveršrnstvovanie tehnologii burovzrwvnwh rabot na predelqnom konture karxerov, izdatelwstvo kolxskij načunwj centar Gornwj Institut, Apatatw.

[11] Lutovac S., Trajković S., Stanić S.: The Effect of Slowing Down Interval on the Oscillation Speed of Soil for the Conditions of the Mine ,Rudnik“, Podzemni radovi No. 14, December 2005, RGF Belgrade, pp. 57-62 (in Serbian).

[12] Lutovac S., Tokalić R., Đinović K.: Shok Wave Measuring While Working the Tunnel for the Needs of the River Cehotina Flow Direction Change, Podzemni radovi No. 15, December 2006, RGF Beograd, pp. 123-132 (in Serbian).

[13] Trajković S., Lutovac S., Tokalić R.: Analysis of the Soil Oscillation Law in the Example of the Open Pit „Kovilovača“, Podzemni radovi No. 16, December 2008, RGF Beograd, pp. 47-56 (in Serbian).

[14] Trajković S., Lutovac S., Ravilić M.: Impact Assessmen on the Environment and Building Structures due to the Blasting at the Open Pit „Nepričava“, Podzemni radovi No. 22, June 2013, RGF Beograd, pp. 33-48 (in Serbian). 


\begin{tabular}{ll}
\hline \hline INSTITUT ZA RUDARSTVO I METALURGIJU BOR & ISSN: 2334-8836 \\
& UDK: 622 \\
\hline \hline
\end{tabular}

\section{O IZVOĐENJU ZAKONA OSCILOVANJA TLA I ODREĐIVANJU NJEGOVIH PARAMETARA**}

\section{Izvod}

U ovom radu izvršena je analiza metode za određivanje parametara zakona oscilovanja tla, koji je predložio ruski profesor M. A. Sadovski, kao i stepen njegove primenljivosti za miniranja sa privrednim eksplozivima za potrebe rudarstva $i$ drugih privrednih delatnosti. Primenljivost ovog zakona, analizirana je na primerima masovnih miniranja na PK „Drenovac“, koja se izvode radi eksploatacije ležišta.

Kao vezu između brzine oscilovanja tla i osnovnih parametara koji utiču na njenu veličinu, a to su: količina eksploziva, rastojanje od mesta miniranja, osobina stenskog materijala $i$ način izvođenja miniranja, najčešće se koristi jednačina $M$. A. Sadovskog, gde je brzina oscilovanja v data u obliku:

$$
v=K \cdot R^{-n},
$$

gde $R$ predstavlja redukovano tj. svedeno rastojanje, a parametri $K i$ in uslovljeni su karakteristikama tla $i$ uslovima miniranja. Pri tome je vopadajuća i konveksna funkcija promenljive $R$.

Za određivanje parametara u jednačini Sadovskog, pored uobičajene metode najmanjih kvadrata primenjen je još jedan model. Pri tom je konstatovano da se oba modela mogu koristiti za izračunavanje brzine oscilovanja stenske mase.

Ključne reči: radna sredina, miniranje, razaranje stena, seizmičko dejstvo, brzina oscilovanja, zakon oscilovanja tla

\section{UVOD}

Za ocenu i kontrolu seizmičkog dejstva miniranja, kao i njegovo planiranje, neophodno je utvrditi zakon oscilovanja tla u pravcu minsko polje - objekti koji se štite. [12]. Jedna od najčešće korišćenih je jednačina M. A. Sadovskog, koja definiše zakon promene brzine oscilovanja tla u zavisnosti od rasto-janja, količine eksploziva, uslova izvođenja miniranja i geoloških karakteristika tla, a određuje se na osnovu probnih miniranja za konkretnu radnu sredinu.
Primenom zakona oscilovanja stenske mase pri miniranju omogućava se da se za svako miniranje unapred odredi brzina oscilovanja tla, a miniranja se u pogledu seizmičkog dejstva stavljaju pod kontrolu, što pruža mogućnost da se veličina potresa za svako sledeće miniranje unapred planira [2]. Na taj način smanjuju se negativni efekti miniranja. Pod negativnim efektima miniranja osim seizmičkog dejstva miniranja podrazumevamo i dejstvo vazdušnog talasa,

\footnotetext{
*Univerzitet u Beogradu, Rudarsko-geološki fakultet, Đušina 7, 11000 Beograd, Srbija, e-mail:suzana.lutovac@rgf.bg.ac.rs; zoran.gligoric@rgf.bg.ac.rs; cedomir.beljic@rgf.bg.ac.rs ${ }^{* *}$ Rad je proistekao iz projekta broj 33025 i 33029 koji je finansiran sredstvima Ministarstva za prosvetu $i$ nauku Republike Srbije, a čiji je realizator Rudarsko-geološki fakultet, Univerziteta u Beogradu
} 
zvučni efekat, razbacivanje odminirane stenske mase itd. [14]. Na taj način povećava se efikasnost proizvodnje i ujedno štite građe-vinski i rudarski objekti u okolini mesta miniranja, kao i životna sredina.

\section{ZAKON OSCILOVANJA TLA}

Za uspostavljanje korelacione veze između brzine oscilovanja i tri osnovna parametra koji utiču na njenu veličinu: količine eksploziva, osobine stenskog materijala i rastojanja, u svetu je razvijeno više modela. Jedan od najčešće korišćenih modela je jednačina Sadovskog, koja definiše zakon promene brzine oscilovanja tla $\mathrm{u}$ zavisnosti od rastojanja, količine eksploziva i načina izvođenja miniranja [9]. Tako definisan zakon pruža mogućnost da odredimo seizmičko dejstvo miniranja u pravcu nekog objekta ili naselja, pri čemu se koristi veza između brzine oscilovanja tla i posledica koje se mogu odraziti na objekte.

Jednačina M. A. Sadovskog data je u obliku:

$$
v=K \cdot\left(\frac{r}{\sqrt[3]{Q}}\right)^{-n}
$$

gde je:

$\mathrm{v}$ - brzina oscilovanja tla $[\mathrm{cm} / \mathrm{s}]$,

$\mathrm{K}$ - koeficijent koji je uslovljen karakteristikama tla i uslovima miniranja, a određuje se terenskim merenjima,

n - eksponent koji je uslovljen karakteristikama tla i uslovima miniranja, a određuje se terenskim merenjima,

r - rastojanje od mesta miniranja do mesta opažanja [m],

$\mathrm{Q}$ - količina eksploziva [kg].

\subsection{Izvođenje jednačine zakona oscilovanja stenske mase}

\subsubsection{Izvođenje jednačine zakona oscilovanja stenske mase - I način}

Jednačina Sadovskog izvedena je iz uslova: ako se radijus punjenja i rastojanje od mesta izvođenja miniranja do mesta opažanja povećavaju u istoj ili približno istoj razmeri brzina oscilovanja tla ostaje ista [1], tj. da je:

$$
v=K_{v} \cdot\left(\frac{r_{o}}{r}\right)^{n}
$$

gde je:

$\mathrm{r}_{\mathrm{o}}$ - radijus eksplozivnog punjenja [m],

$\mathrm{r}$ - rastojanje od mesta miniranja do mesta opažanja [m].

Radijus eksplozivnog punjenja $\left(\mathrm{r}_{0}\right) \mathrm{i}$ količina eksploziva (Q) vezani su jednačinom:

$$
Q=\frac{4}{3} \cdot \pi \cdot r_{o}^{3},
$$

odakle je:

$$
r_{o}=\sqrt[3]{\frac{3 \cdot Q}{4 \cdot \pi}} .
$$

Zamenom vrednosti $\left(r_{0}\right)$ iz jednačine (4) u jednačini (2) dobijamo:

$$
\begin{aligned}
& v=K_{v} \cdot\left(\frac{\sqrt[3]{\frac{3 \cdot Q}{4 \cdot \pi}}}{r}\right)^{n}=K_{v} \cdot\left(\sqrt[3]{\frac{3}{4 \cdot \pi}}\right)^{n} \cdot\left(\frac{\sqrt[3]{Q}}{r}\right)^{n}= \\
& =K_{v} \cdot K_{1} \cdot\left(\frac{r}{\sqrt[3]{Q}}\right)^{-n}=K \cdot\left(\frac{r}{\sqrt[3]{Q}}\right)^{-n}=K \cdot R^{-n}
\end{aligned}
$$

gde je:

$$
\left(\sqrt[3]{\frac{3}{4 \cdot \pi}}\right)^{n}=K_{1}
$$

$K_{v} \cdot K_{1}=K$;

$\frac{r}{\sqrt[3]{Q}}=R$

$\mathrm{R}$ - redukovano rastojanje ili svedeno rastojanje predstavlja rastojanje od mesta miniranja do mesta opažanja svedeno na količinu eksploziva, a dato u obliku $R=\frac{r}{r_{0}}$ 
Na taj način dobili smo zakon oscilovanja stenske mase tj. jednačinu Sadovskog $u$ obliku:

$$
v=K \cdot R^{-n}
$$

\subsubsection{Izvođenje jednačine zakona oscilovanja stenske mase - II način}

Ako se pri miniranju u datoj sredini posmatraju relativni priraštaji brzine oscilovanja stenske mase i relativni priraštaji redukovanog rastojanja [8(A)], onda se može videti da njihovi odnosi pri raznim nivoima imaju približno istu vrednost koju ćemo označiti sa (-n), što znači da je:

$$
\frac{\frac{\Delta v}{v}}{\frac{\Delta R}{R}} \approx-n
$$

Pri tome se može uzeti da je:

$$
\lim _{\Delta R \rightarrow 0} \frac{\frac{\Delta v}{v}}{\frac{\Delta R}{R}}=-n,
$$

što znači da je:

$$
\frac{\frac{d v}{v}}{\frac{d R}{R}}=-n .
$$
obliku:

Jednačinu (7) možemo napisati u

$$
\frac{d v}{v}=-n \cdot \frac{d R}{R},
$$

odakle se integracijom dobija:

$$
\int \frac{d v}{v}=-n \cdot \int \frac{d R}{R},
$$

odnosno:

$$
\log v=\log R^{-n}+\log K
$$

gde je:

$\mathrm{K}$ - konstanta integracije.

Jednačina (8) može se napisati u obliku:

$\log v=\log k \cdot R^{-n}$, odakle se dobija:

$$
v=K \cdot R^{-n},
$$

a to je jednačina oscilovanja stenske mase M.A. Sadovskog.

Jednačina Sadovskog često se iskazuje u obliku:

$$
v=K \cdot Q_{\text {red }}^{n}
$$

gde je:

$\mathrm{Q}_{\text {red }}$ - redukovana količina eksploziva

$$
Q_{\text {red }}=\frac{\sqrt[3]{Q}}{r}
$$

gde je:

$\mathrm{r}$ - rastojanje od mesta miniranja do mesta opažanja [m],

Q - ukupna količina eksploziva u minskoj seriji [kg].

\subsection{Modeli određivanja parametara zakona oscilovanja tla}

U jednačini (5) javljaju se dva parametra $\mathrm{K}$ i n, koje treba odrediti za konkretnu radnu sredinu i pri određenim uslovima miniranja. S obzirom na svojstvo zakona oscilovanja stenske mase, moguće je parametre $\mathrm{K}$ i $\mathrm{n}$ odrediti na više načina tj. modela, koristeći pri tome vrednosti dobijene eksperimentalnim merenjima.

\subsubsection{Određivanje parametara po modelu 1}

$\mathrm{Za}$ dobijanje parameatra (K) i (n) uglavnom se koristi metoda najmanjih kvadrata, koja predstavlja uobičajeni model [3]. Jednačina (5) se logaritmuje i tako svodi na sledeći oblik:

$$
\log v=\log K-n \log R
$$

Uvođenjem zamene: $\mathrm{v}=\mathrm{y} ; \mathrm{K}=\mathrm{a} ; \mathrm{R}=\mathrm{x}$; $\mathrm{n}=\mathrm{b}$; jednačina dobija sledeći oblik:

$$
\log a-b \log x=\log y
$$


Normalan sistem jednačina za nalaženje parametara (a) i (b) u ovom slučaju glasi:

$$
\begin{aligned}
& N \log a-b \sum_{i=1}^{N} \log x_{i}=\sum_{i=1}^{N} \log y_{i} \\
& (\log a) \sum_{i=1}^{N} \log x_{i}-b \sum_{i=1}^{N}\left(\log x_{i}\right)^{2}=\sum_{i=1}^{N} \log x_{i} \cdot \log y_{i}
\end{aligned}
$$

gde je:

$$
\mathrm{N} \text { - broj izvršenih merenja. }
$$

\subsubsection{Odredivanje parametara po modelu 2}

Polazeći od zakona za brzinu oscilovanja stenske mase iz jednačine (5):

$$
v=K \cdot R^{-n},
$$

koji je izveden na drugi način (poglavlje 2.1.2), pri čemu parametar K, koji se pojavio kao konstanta integracije [8(B)], možemo da odredimo iz uslova (početnog uslova) da za $\mathrm{R}=\mathrm{R}_{1}$ bude $\mathrm{v}=\mathrm{v}_{1}$.

Parametre $\mathrm{K}$ i $\mathrm{n}$ odredićemo koristeći eksperimentalne podatke parova $\left(\mathrm{R}_{\mathrm{i}}, \mathrm{v}_{\mathrm{i}}\right)$, $\mathrm{i}=1,2, \ldots, \mathrm{N}$, uz uslov da kriva brzine oscilovanja stenske mase prolazi kroz tačku $\mathrm{M}_{1}\left(\mathrm{R}_{1}, \mathrm{v}_{1}\right)$. U tom slučaju iz (2.5) za $\mathrm{R}=\mathrm{R}_{1} \mathrm{i}$ $\mathrm{v}=\mathrm{v}_{1}$ dobijamo:

$$
v_{1}=K \cdot R_{1}^{-n},
$$

odakle je:

$$
K=v_{1} \cdot R_{1}^{n} .
$$

Zamenom vrednosti za K iz (14) u jednačini (5) dobijamo jednačinu:

$$
v=v_{1} \cdot\left(\frac{R_{1}}{R}\right)^{n} .
$$

Iz jednačine (15) se za $R=R_{1}$ dobija $\mathrm{v}=\mathrm{v}_{1}$ za bilo koje $\mathrm{n}$, $\mathrm{u}$ našem slučaju $\mathrm{n}>0$. $\mathrm{Za} \mathrm{R}=\mathrm{R}_{\mathrm{i}}, \mathrm{i}=2,3, \ldots, \mathrm{N}$, iz jednačine $(15)$ možemo uzeti da je:

$$
v_{i}=v_{1} \cdot\left(\frac{R_{1}}{R_{i}}\right)^{n}, \mathrm{i}=2,3, \ldots, \mathrm{N},
$$

odakle se dobija relacija:

$$
v_{1} \cdot v_{2} \cdot \ldots \cdot v_{N}=v_{1}^{N} \cdot\left(\frac{R_{1}^{N}}{R \cdot{ }_{1} R_{2} \cdot \ldots \cdot R_{N}}\right)^{n} .
$$

Iz relacije (16) možemo odrediti parametar n. Logaritmovanjem relacije (16) dobijamo:

$$
n \log \left(\frac{R_{1}^{N}}{R_{1} \cdot R_{2} \cdot \ldots \cdot R_{N}}\right)=\log \left(\frac{v_{1} \cdot v_{2} \cdot \ldots \cdot v_{N}}{v_{1}^{N}}\right),
$$

odakle nalazimo:

$$
n=\frac{\log \left(\frac{v_{1} \cdot v_{2} \cdot \ldots \cdot v_{N}}{v_{1}^{N}}\right)}{\log \left(\frac{R_{1}^{N}}{R_{1} \cdot R_{2} \cdot \ldots \cdot R_{N}}\right)} .
$$

Zamenom ovako nađene vrednosti za parametar $\mathrm{n}$ u jednačini (17), dobijamo za brzinu oscilovanja stenske mase u posmatranoj sredini relaciju:

$$
v=v_{1} \cdot\left(\frac{R_{1}}{R}\right)^{n} .
$$

$\mathrm{Na}$ ovaj način za određivanje parametra n uzeti su u obzir svi eksperimentalni podaci.

\section{DEFINISANJE STATISTIČKIH KRITERIJUMA}

Za ocenu stepena povezanosti između registrovanih (izmerenih) i izračunatih podataka u ovom radu koristili smo koeficijent linearne korelacije $r$ [5] između logaritama redukovanog rastojanja $\mathrm{R}$ i logaritama brzine oscilovanja v. Pored toga, uzimali smo u obzir i indeks krivolinijske zavisnosti $\rho[6(\mathrm{~A})]$ između redukovanog rastojanja $\mathrm{R}$ i brzine oscilovanja $\mathrm{v}$.

Ocena stepena povezanosti dve promenljive [13] prema vrednostima indeksa krivolinijske zavisnosti $\rho$ data je $\mathrm{u}$ narednom pregledu: 
$0,0<\rho<0,2$ nikakva ili veoma slaba veza,

$0,2<\rho<0,4$ slaba povezanost,

$0,4<\rho<0,7$ značajna povezanost,

$0,7<\rho<1,0$ jaka ili vrlo jaka povezanost.

Isto važi i za apsolutnu vrednost koeficijenta linearne korelacije r.

Kao mera pogodnosti dobijene funkcionalne veze za date eksperimentalne podatke koristili smo i kriterijum „3S“ [6(B)]. Ovaj kriterijum koristi kvadrate razlika između dobijenih eksperimentalnih podataka i izračunatih podataka za brzine oscilovanja $\mathrm{v}$. Ako su te razlike redom $\varepsilon_{1}, \varepsilon_{2} \ldots \varepsilon_{\mathrm{N}}$, tada je:

$$
S=\sqrt{\frac{\varepsilon_{1}^{2}+\varepsilon_{2}^{2}+\ldots+\varepsilon_{N}^{2}}{N}}
$$

Prema ovom kriterijumu, za ocenu pogodnosti dobijene funkcionalne veze važe sledeći odnosi:

- ako je $\left|\varepsilon_{\max }\right|>3 \mathrm{~S}$, odbacuje se dobijena funkcionalna veza kao nepovoljna,

- ako je $\left|\varepsilon_{\max }\right|<3 \mathrm{~S}$, prihvata se funkcionalna veza kao dobra.

\section{PRIKAZ MASOVNIH MINIRANJA NA PK ,DRENOVAC““}

\subsection{Opšte karakteristike površinskog kopa „Drenovac"}

Ovaj rad obuhvata ispitivanja koja su izvršena pri masovnim miniranjima na površinskom kopu „Drenovac“ - Mionica [7(A)]. Površinski kop "Drenovac" je visinskog tipa i nalazi se gotovo na samom vrhu istoimenog brda. Merenja su izvršena na masivnim ili slojevitim krečnjacima.

Ležište krečnjaka zahvata površinu od 7,7 ha. Visinska razlika ležišta je oko $70 \mathrm{~m}$, od kote 440-520 m. U podini krečnjaka je dijabaz - rožna formacija i ona se približno nalazi na koti oko 438 m.
Kartiranjem terena i istražnih bušotina konstatovano je da je krečnjak prslinsko pukotinske poroznosti. Dužina kernova je od $30-40 \mathrm{~cm}$. Prsline i pukotine su najvećim delom zapunjene kalcitom, u manjem obimu pukotine su zapunjene limonitisanom drobinom, odnosno skramama limonita. Prilikom bušenja vrlo malo se gubila isplaka voda, što ukazuje da je efektivna porozonost krečnjaka mala.

Krečnjak je čvrsta dobro okamenjena sredina. Tektonski je neoštećena tako da predstavlja jedinstvenu monolitnu masu. Prisutne prsline i pukotine malo utiču na opšte fizičko-mehaničke karakteristike. Ispitivanjem fizičko-mehaničkih osobina radne sredine dobijene su sledeće vrednosti:

$$
\begin{array}{lc}
\text { - zapreminska masa } & 2,68\left[\mathrm{kN} / \mathrm{m}^{3}\right] \\
\text { - poroznost } & 0,7-1,5[\%] \\
\text { - kohezija } & 0,25[\mathrm{MPa}] \\
\text { - jednoaksijalna čvrstoća } \\
\text { - u suvom stanju } \quad 120-134[\mathrm{MPa}] \\
\text { - u vodozasićenom stanju } \\
\multicolumn{2}{c}{83-129[\mathrm{MPa}]} \\
\text { - ugao unutrašnjeg trenja } 41\left[^{\circ}\right] .
\end{array}
$$

\subsection{Način izvođenja miniranja}

Merenja seizmičkih potresa na PK „Drenovac“ obavljena su pri miniranjima koja se izvode radi eksploatacije ležišta [7(B)]. Izvedeno je osam miniranja.

Kao eksploziv korišćen je amonex-1 28/200, amonex-1 60/1000, ANFO-J u vrećama od $25 \mathrm{~kg}$ i ANFEX-PP 70/1500. Aktiviranje eksploziva u bušotinama vršeno je nonel detonatorima, oznake N-25/500 i konektorima K-42. Osnovni podaci vezani za broj bušotina $\left(\mathrm{N}_{\mathrm{b}}\right)$, ukupnu količinu eksploziva $\mathrm{Q}_{\mathrm{uk}}$, maksimalnu količinu eksploziva po intervalu usporenja $\mathrm{Q}_{\mathrm{i}}$, ukupnu dubinu bušotina $\mathrm{L}_{\mathrm{uk}}$, i prosečnu dužinu čepa $\mathrm{L}_{\mathrm{pč}}$, dati su u tabeli 1. 
Tabela 1. Prikaz parametara miniranja

\begin{tabular}{|c|c|c|c|c|c||}
\hline Miniranje & $\mathbf{N}_{\mathbf{b}}$ & $\mathbf{Q}_{\mathbf{u k}}[\mathbf{k g}]$ & $\mathbf{Q}_{\mathbf{i}}[\mathbf{k g}]$ & $\mathbf{L}_{\mathbf{u k}}[\mathbf{m}]$ & $\left.\mathbf{L}_{\mathbf{p c}} \mathbf{m}\right]$ \\
\hline \hline I & 27 & 661,4 & 36,2 & 211,0 & $2,8-3,0$ \\
\hline II & 28 & $1.980,6$ & 71,2 & 488,0 & $2,8-3,0$ \\
\hline III & 15 & 915,3 & 66,2 & 213,0 & $2,8-3,0$ \\
\hline IV & 16 & 745,0 & 47,0 & 175,0 & $3,0-3,2$ \\
\hline V & 40 & $1.895,0$ & 60,5 & 453,0 & $3,0-3,2$ \\
\hline VI & 22 & $1.774,4$ & 85,2 & 402,0 & $3,0-3,2$ \\
\hline VII & 43 & $1.988,6$ & 54,2 & 518,0 & $3,0-3,2$ \\
\hline VIII & 20 & 600 & 32,0 & 273,0 & $3,0-3,5$ \\
\hline
\end{tabular}

Na slici 1. prikazan je snimak brzine mesto broj 3 . oscilovanja tla za miniranje broj I - merno

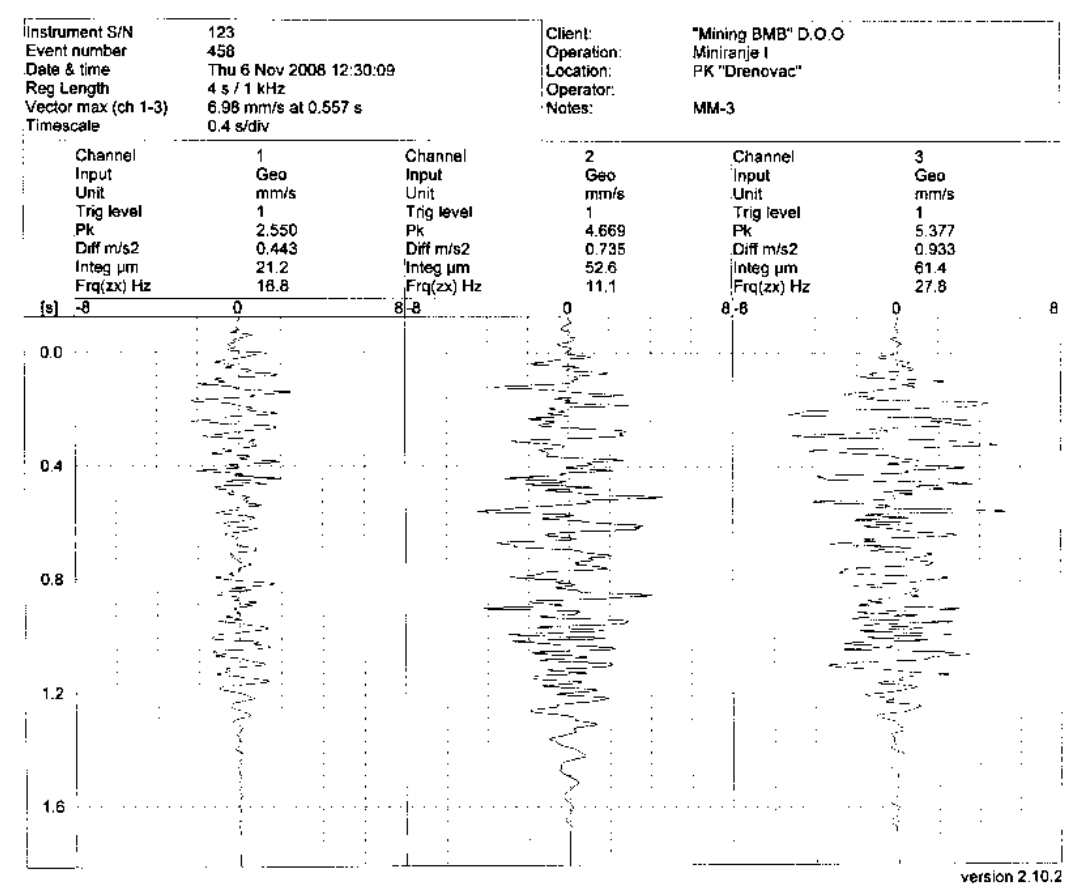

SI. 1. Snimak brzine oscilovanja tla za miniranje I-MM3

\subsection{Proračun parametara zakona} oscilovanja tla

Vrednosti rastojanja od mesta miniranja do mesta opažanja r, količina eksploziva Q, izračunate vrednosti redukovanih rastojanja $\mathrm{R}$, registrovane vrednosti brzina oscilovanja tla po komponentama $\mathrm{v}_{\mathrm{t}}, \mathrm{v}_{\mathrm{v}}, \mathrm{v}_{\mathrm{l}}$ i rezultujuće brzine oscilovanja $\mathrm{v}_{\text {rez }}$ za miniranja od I VIII na ukupno sedam mernih mesta MM date su u tabeli 2. 
Tabela 2. Prikaz parametara miniranja i rezultata merenja

\begin{tabular}{|c|c|c|c|c|c|c|c|c|c|}
\hline R. b. & $\begin{array}{c}\text { Min } \\
\text { b. }\end{array}$ & MM & $\mathbf{r}[\mathbf{m}]$ & $\mathrm{Q}[\mathrm{kg}]$ & $\mathbf{R}$ & $\mathbf{v}_{t}[\mathrm{~cm} / \mathrm{s}]$ & $\left.\begin{array}{c}\mathbf{v}_{\mathbf{v}} \\
{[\mathrm{cm} / \mathrm{s}]}\end{array}\right]$ & $\begin{array}{c}\mathbf{v}_{1} \\
{[\mathrm{~cm} / \mathrm{s}]}\end{array}$ & $\begin{array}{c}V_{\text {Irz }} \\
{[\mathrm{cm} / \mathrm{s}]}\end{array}$ \\
\hline 1 & I & $\mathrm{MM}-2$ & 383,87 & 661,4 & 44,0585 & 0,070 & 0,100 & 0,110 & 0,1643 \\
\hline 2 & I & $M M-3$ & 250,49 & 661,4 & 28,7499 & 0,255 & 0,466 & 0,537 & 0,7616 \\
\hline 3 & I & MM - 5 & 647,42 & 661,4 & 74,3073 & 0,080 & 0,090 & 0,080 & 0,1446 \\
\hline 4 & II & MM - 1 & 605,54 & 1980,6 & 48,2182 & 0,060 & 0,060 & 0,070 & 0,1100 \\
\hline 5 & II & $M M-2$ & 334,15 & 1980,6 & 26,6078 & 0,080 & 0,120 & 0,150 & 0,2081 \\
\hline 6 & II & $M M-3$ & 256,71 & 1980,6 & 28,4042 & 0,510 & 0,500 & 1,090 & 1,3031 \\
\hline 7 & II & $M M-6$ & 527,05 & 1980,6 & 41,9681 & 0,090 & 0,230 & 0,160 & 0,2943 \\
\hline 8 & III & $\mathrm{MM}-1$ & 616,35 & 915,3 & 63,4804 & 0,091 & 0,083 & 0,082 & 0,1482 \\
\hline 9 & III & $\mathrm{MM}-2$ & 250,14 & 915,3 & 25,7629 & 0,192 & 0,573 & 0,719 & 0,9392 \\
\hline 10 & III & $\mathrm{MM}-3$ & 412,66 & 915,3 & 42,5015 & 0,380 & 0,605 & 0,412 & 0,8247 \\
\hline 11 & III & $\mathrm{MM}-5$ & 714,10 & 915,3 & 73,5481 & 0,138 & 0,096 & 0,116 & 0,2045 \\
\hline 12 & III & $M M-6$ & 541,13 & 915,3 & 55,7332 & 0,170 & 0,241 & 0,177 & 0,3454 \\
\hline 13 & III & $\mathrm{MM}-7$ & 530,89 & 915,3 & 54,6785 & 0,133 & 0,236 & 0,193 & 0,3326 \\
\hline 14 & IV & MM - 1 & 723,77 & 745,0 & 79,8390 & 0,060 & 0.080 & 0,070 & 0,1221 \\
\hline 15 & IV & $\mathrm{MM}-2$ & 410,33 & 745,0 & 45,2635 & 0,140 & 0,170 & 0,180 & 0,2844 \\
\hline 16 & IV & $\mathrm{MM}-3$ & 223,89 & 745,0 & 24,6973 & 0,310 & 0,420 & 0,540 & 0,7511 \\
\hline 17 & IV & $M M-5$ & 644,64 & 745,0 & 71,1102 & 0,110 & 0,200 & 0,200 & 0,3035 \\
\hline 18 & IV & $\mathrm{MM}-7$ & 426,38 & 745,0 & 47,0339 & 0,200 & 0,230 & 0,210 & 0,3701 \\
\hline 19 & V & $\mathrm{MM}-1$ & 737,38 & 1895,0 & 60,0667 & 0,050 & 0,070 & 0,040 & 0,0948 \\
\hline 20 & V & $\mathrm{MM}-3$ & 210,96 & 1895,0 & 17,1847 & 0,550 & 0,790 & 1,150 & 1,4996 \\
\hline 21 & $\mathrm{~V}$ & $\mathrm{MM}-7$ & 422,53 & 1895,0 & 34,4192 & 0,210 & 0,360 & 0,320 & 0,5254 \\
\hline 22 & VI & $\mathrm{MM}-3$ & 231,44 & 1774,4 & 19,1171 & 0,577 & 1,160 & 0,709 & 1,4768 \\
\hline 23 & VI & $M M-5$ & 650,53 & 1774,4 & 53,7341 & 0,055 & 0,071 & 0,077 & 0,1165 \\
\hline 24 & VI & MM - 6 & 640,06 & 1774,4 & 52,8693 & 0,081 & 0,150 & 0,168 & 0,2393 \\
\hline 25 & VI & $\mathrm{MM}-7$ & 425,36 & 1774,4 & 35,1350 & 0,340 & 0,465 & 0,259 & 0,6316 \\
\hline 26 & VII & $\mathrm{MM}-3$ & 333,13 & 1988,6 & 26,4910 & 0,534 & 0,460 & 0,602 & 0,9268 \\
\hline 27 & VII & $M M-6$ & 530,48 & 1988,6 & 42,1845 & 0,101 & 0,190 & 0,150 & 0,2623 \\
\hline 28 & VII & $\mathrm{MM}-7$ & 415,31 & 1988,6 & 33,0260 & 0,284 & 0,525 & 0,286 & 0,6618 \\
\hline 29 & VIII & $\mathrm{MM}-1$ & 609,20 & 600,0 & 72,2286 & 0,030 & 0,070 & 0,070 & 0,1034 \\
\hline 30 & VIII & $M M-3$ & 387,35 & 600,0 & 45,9254 & 0,339 & 0,527 & 0,629 & 0,8878 \\
\hline 31 & VIII & $M M-6$ & 532,35 & 600,0 & 63,1171 & 0,067 & 0,112 & 0,079 & 0,1607 \\
\hline 32 & VIII & $\mathrm{MM}-7$ & 493,85 & 600,0 & 58,5524 & 0,072 & 0,157 & 0,156 & 0,2327 \\
\hline
\end{tabular}

\section{$\checkmark$ Model 1}

$$
v_{1}=166,3916 \cdot R^{-1,6433}
$$

pri čemu je između log v i log R dobijena linearna zavisnost, izražena jednačinom (20) sa koeficijentom linearne zavisnosti $r$ koji iznosi:

$$
\mathrm{r}=-0,8
$$

Grafički prikaz zakona oscilovanja tla dat je na slici 2 . 


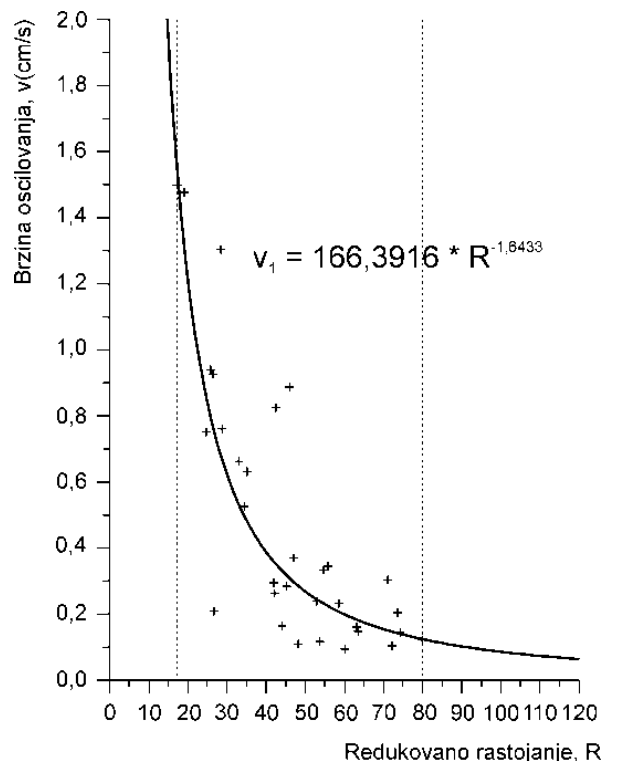

SI. 2. Grafički prikaz krive brzine oscilovanja tla na PK „Drenovac“

\section{- Model 2}

$$
v_{2}=143,2699 \cdot R^{-1,6032}
$$

$\mathrm{Na}$ osnovu dobijenih jednačina oscilovanja tla (20) i (21), moguće je izračunati vrednosti brzina oscilovanja tla za odgovarajuća redukovana rastojanja za model 1 i 2.
U tabeli 3. dat je pregled redukovanih rastojanja $R$, registrovanih brzina oscilovanja tla $v_{r}$, izračunatih brzina oscilovanja tla $v_{i 1}$, $\mathrm{v}_{\mathrm{i} 2}$, kao i razlika između registrovanih i izračunatih brzina oscilovanja tla za model 1 i 2.

Tabela 3. Prikaz registrovanih i izračunatih brzina oscilovanja tla za model 1 i 2

\begin{tabular}{|c|c|c|c|c|c|c|}
\hline Redni br. & $\mathbf{R}$ & $\mathrm{v}_{\mathrm{r}}[\mathrm{cm} / \mathrm{s}]$ & $\mathrm{v}_{\mathrm{i} 1}[\mathrm{~cm} / \mathrm{s}]$ & $\mathrm{v}_{\mathrm{i} 2}[\mathrm{~cm} / \mathrm{s}]$ & $\overline{v_{r}-v_{i 1}}$ & $\overline{v_{r}-v_{i 2}}$ \\
\hline 1 & 44,0585 & 0,1643 & 0,3307 & 1,4996 & $-0,1664$ & 0,0000 \\
\hline 2 & 28,7499 & 0,7616 & 0,6670 & 1,2641 & 0,0946 & 0,2127 \\
\hline 3 & 74,3073 & 0,1446 & 0,1401 & 0,8384 & 0,0045 & $-0,0873$ \\
\hline 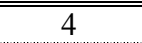 & 48,2182 & 0,1100 & 0,2852 & 0,7835 & $-0,1752$ & 0,1557 \\
\hline 5 & 26,6078 & 0,2081 & 0,7576 & 0,7493 & $-0,5495$ & 0,1775 \\
\hline 6 & 28,4042 & 1,3031 & 0,6804 & 0,7440 & 0,6227 & $-0,5359$ \\
\hline 7 & 41,9681 & 0,2943 & 0,3583 & 0,6700 & $-0,0640$ & 0,6331 \\
\hline 8 & 63,4804 & 0,1482 & 0,1815 & 0,6572 & $-0,0333$ & $\overline{00,1044}$ \\
\hline 9 & 25,7629 & 0,9392 & 0,7988 & 0,5262 & 0,1404 & 0,1356 \\
\hline 10 & 42,5015 & 0,8247 & 0,3509 & 0,4924 & 0,4738 & 0,0330 \\
\hline 11 & 73,5481 & 0,2045 & 0,1425 & 0,4765 & 0,0620 & 0,1551 \\
\hline 12 & 55,7332 & 0,3454 & 0,2248 & 0,3583 & 0,1206 & $-0,0640$ \\
\hline 13 & 54,6785 & 0,3326 & 0,2319 & 0,3554 & 0,1007 & $-0,0931$ \\
\hline
\end{tabular}




\begin{tabular}{|c|c|c|c|c|c|c||}
\hline 14 & 79,8390 & 0,1221 & 0,1245 & 0,3512 & $-0,0024$ & 0,4735 \\
\hline 15 & 45,2635 & 0,2844 & 0,3164 & 0,3315 & $-0,0320$ & $-0,1672$ \\
\hline 16 & 24,6973 & 0,7511 & 0,8562 & 0,3174 & $-0,1051$ & $-0,0330$ \\
\hline 17 & 71,1102 & 0,3035 & 0,1506 & 0,3101 & 0,1529 & 0,5777 \\
\hline 18 & 47,0339 & 0,3701 & 0,2971 & 0,2985 & 0,0730 & 0,0716 \\
\hline \hline 19 & 60,0667 & 0,0948 & 0,1987 & 0,2868 & $-0,1039$ & $-0,1768$ \\
\hline 20 & 17,1847 & 1,4996 & 1,5539 & 0,2475 & $-0,0543$ & $-0,0082$ \\
\hline 21 & 34,4192 & 0,5254 & 0,4963 & 0,2411 & 0,0291 & $-0,1246$ \\
\hline \hline 22 & 19,1171 & 1,4768 & 1,3043 & 0,2345 & 0,1725 & 0,0981 \\
\hline 23 & 53,7341 & 0,1165 & 0,2387 & 0,2274 & $-0,1222$ & 0,1180 \\
\hline 24 & 52,8693 & 0,2393 & 0,2451 & 0,2101 & $-0,0058$ & 0,0226 \\
\hline 25 & 35,1350 & 0,6316 & 0,4798 & 0,2017 & 0,1518 & $-0,1069$ \\
\hline 26 & 26,4910 & 0,9268 & 0,7631 & 0,1863 & 0,1637 & $-0,0256$ \\
\hline 27 & 42,1845 & 0,2623 & 0,3552 & 0,1846 & $-0,0929$ & $-0,0364$ \\
\hline 28 & 33,0260 & 0,6618 & 0,5311 & 0,1539 & 0,1307 & 0,1496 \\
\hline \hline 29 & 72,2286 & 0,1034 & 0,1468 & 0,1501 & $-0,0434$ & $-0,0467$ \\
\hline 30 & 45,9254 & 0,8878 & 0,3089 & 0,1458 & 0,5789 & 0,0587 \\
\hline 31 & 63,1171 & 0,1607 & 0,1832 & 0,1434 & $-0,0225$ & 0,0012 \\
\hline 32 & 58,5524 & 0,2327 & 0,2073 & 0,1278 & 0,0254 & $-0,0057$ \\
\hline \hline
\end{tabular}

Na osnovu podataka iz tabele 3. izvršena je statistička analiza i dobijene su sledeće vrednosti.

\section{Model 1:}

Indeks krivolinijske zavisnosti $\rho_{1}$ između redukovanog rastojanja $\mathrm{R}$ i brzine oscilovanja tla $v$, iznosi:

$$
\begin{gathered}
\rho_{1}=0,8380 \text { (postoji vrlo jaka povezanost } \\
\text { između R i v, data } \mathrm{u} \\
\text { formuli }(20) \text { ). }
\end{gathered}
$$

Maksimalna razlika između registrovanih i izračunatih brzina oscilovanja tla $\left(\varepsilon_{\max }\right)=\max \left|\varepsilon_{i}\right|$, iznosi:

$$
\begin{aligned}
& \varepsilon_{\max 1}=0,6227, \mathrm{~S}_{1}=0,2200, \\
& 3 \mathrm{~S}_{1}=0,6600 .
\end{aligned}
$$

Pošto je $\varepsilon_{\max 1}<3 \mathrm{~S}_{1}$, pretpostavljena funkcionalna veza se prihvata kao dobra.

\section{Model 2:}

$$
\begin{gathered}
\rho_{2}=0,8357 \text { (postoji vrlo jaka povezanost } \\
\text { između R i v, data u for- } \\
\text { muli }(21) \text { ). } \\
\varepsilon_{\max 2}=0,6331, \mathrm{~S}_{2}=0,2214,
\end{gathered}
$$

$$
\begin{aligned}
& 3 \mathrm{~S}_{2}=0,6642 . \\
& \varepsilon_{\max 2}<3 \mathrm{~S}_{2} \text { (pretpostavljena funkcionalna } \\
& \text { veza prihvata se kao dobra). }
\end{aligned}
$$

\section{ZAKLJUČAK}

Za uspostavljanje veze između brzine oscilovanja stenske mase i osnovnih parametara koji utiču na njenu veličinu, a to su: količina eksploziva, rastojenje od mesta miniranja, osobina stenskog materijala i način izvođenja miniranja, najčešće se koristi jednačina profesora M. A. Sadovskog, koja definiše zakon promene brzine oscilovanja stenske mase i data je u obliku funkcije:

$$
v=K \cdot R^{-n},
$$

gde $\mathrm{R}$ predstavlja redukovano tj. svedeno rastojanje, a parametri $\mathrm{K}$ i $\mathrm{n}$ koeficijent $\mathrm{i}$ eksponent koji su uslovljeni karakteristikama tla i uslovima miniranja i mogu imati samo pozitivne vrednosti. Pri tome je v opadajuća i konveksna funkcija.

U radu je zakon Sadovskog izveden i na drugi način, korišćenjem količnika odnosa između relativnih priraštaja brzina oscilovanja stenske mase i relativnih priraštaja redukovanih rastojanja. Pri tome je $\mathrm{u}$ 
graničnom slučaju dobijena jedna diferencijalna jednačina čiji se opšti integral poklapa sa zakonom Sadovskog.

U ovom radu, izračunata je brzina oscilovanja, tj. određeni su parametri $\mathrm{K}$ i $\mathrm{n}$ na dva načina - modela. Analizom i obradom dobijenih podataka može se zaključiti:

Parametri n i K u zakonu Sadovskog određivani su na dva načina - modela $u$ datoj radnoj sredini. Pri tome su dobijene odgovarajuće funkcije kojima su predstavljene brzine oscilovanja stenske mase $\mathrm{u}$ zavisnosti od redukovanog rastojanja. Izračunati odgovarajući indeksi krivolinijske korelacije pokazuju da između redukovanog rastojanja i brzine oscilovanja stenske mase postoji vrlo jaka krivolinijska veza izražena dobijenim funkcijama.

Upoređujući vrednosti registrovanih brzina oscilovanja stenske mase sa odgovarajućim izračunatim vrednostima, vidimo da one imaju približno iste vrednosti. $\mathrm{Na}$ osnovu dobijenih vrednosti koeficijenata krivolinijske zavisnosti i vrednosti koeficijenata linearne korelacije između logaritama redukovanog rastojanja i logaritama brzine oscilovanja zaključujemo da se oba modela mogu koristiti za izračunavanje brzine oscilovanja stenske mase.

\section{LITERATURA}

[1] Medvedev S. V. (1964): Seismika gornwh vzrwvov, Nedra, Moskva, str. 42-43.

[2] Trajković S., Slimak Š., Lutovac S. (2005): Tehnika miniranja i potresi, RGF Beograd, str. 199

[3] Simeunović D. (1985): Matematika, RGF - Rudarski odsek, Beograd, str. 102-103

[4] Ivanović B. (1973): Teorijska statistika, Naučna knjiga, Beograd.

[5] Simonović V. (1995): Uvod u teoriju verovatnoće i matematičku statistiku, TEKON - Tehnokonsalting, Beograd, str. 90.

[6] Vukadinović S. (1970): Elementi računa verovatnoće i matematičke statistike, Tehnika za umnožavanje Biroa za građevinarstvo, Beograd, str. str. 346(A), str. 329-331(B)

[7] Trajković S., Lutovac S., Katona O. (2009): Studija seizmičkih i vazdušnih uticaja na okolne građevinske objekte kao posledica izvođenja miniranja na PK "Drenovac" - kod Mionice, RGF Beograd, str. 3-4(A), str. 15-51(B).

[8] Lutovac S.; (2010). Model određivanja parametara zakona oscilovanja stenske mase pri miniranju, Doktorska disertacija, RGF Beograd, str. 3435(A), str. 40-41(B).

[9] Savić M. (2000): Miniranje na površinskim kopovima, Monografija, RTB Bor Institut za bakar Bor, Indok centar, Bor, str. 317

[10] Fokin V. A., Tarasov G. E., Togunov M. B., Danilkin A. A., Šitov Y. A. (2008): Soveršrnstvovanie tehnologii burovzrwvnwh rabot na predelqnom konture karxerov, Izdatelwstvo Kolxskij naučnwj CENTAR Gornwj institut, Apatatw.

[11] Lutovac S., Trajković S., Stanić S.: Uticaj intervala usporenja na brzinu oscilovanja tla za uslove rud-nika „Rudnik“, Podzemni radovi br. 14, decembar 2005, RGF Beograd, str. 57-62.

[12] Lutovac S., Tokalić R., Đinović K.: Shok Wave Measuring While Working the Tunnel for the Needs of the River Cehotina Flow Direction Change, Podzemni radovi br. 15, decembar 2006, RGF Beograd, str. 123-132.

[13] Trajković S., Lutovac S., Tokalić R.: Analiza zakona oscilovanja tla na primeru PK „Kovilovača“, Podzemni radovi br. 16, decembar 2008, RGF Beograd, str. 47-56.

[14] Trajković S., Lutovac S., Ravilić M.: Procena uticaja na životnu sredinu i građevinske objekte usled miniranja na PK ,Nepričava“, Podzemni radovi br. 22, jun 2013, RGF Beograd, str. 33-48 